\title{
UJI TOKSISITAS EKSTRAK KULIT JERUK LEMON (Citrus limon (L.) Osbeck) TERHADAP LARVA UDANG (Artemia salina Leach)
}

\author{
Nur Hasanah, Ika Yulianti \\ Sekolah Tinggi Ilmu Kesehatan Kharisma Persada \\ Tangerang Selatan, 15417 \\ E-mail:nurhasanah@masda.ac.id
}

\begin{abstract}
ABSTRAK
Salah satu tanaman di Indonesia yang sangat terkenal yaitu jeruk lemon (Citrus limon (L.) Osbeck). Kulit jeruk lemon mengandung senyawa metabolit sekunder flavonoid, tanin, steroid, dan triterpenoid. Senyawa flavonoid dan triterpenoid diduga dapat bersifat toksik pada kadar tertentu. Untuk itu perlu dilakukannya uji toksisitas, salah satu pengujian toksisitas dengan menggunakan metode Brine Shrimp Lethaly Test (BSLT). Aktivitas toksik diketahui dari jumlah kematian larva udang karena pengaruh ekstrak pada konsentrasi yang diberikan. Penelitian ini bertujuan untuk mengetahui potensi toksik pada ekstrak etanol, fase n-heksana dan fase etil asetat dan mengetahui nilai $\mathrm{LC}_{50}$ tertinggi pada ekstrak etanol, fase n-heksana dan fase etil asetat. Penelitian ini menggunakan jenis penelitian true eksperimental. Sampel yang digunakan adalah ekstrak etanol kulit jeruk lemon sebagai zat aktif, kemudian di partisi dengan n-heksan dan etil asetat. Lalu dibuat larutan uji 1000 ppm, 600 ppm, 400 ppm, 200 ppm, 100 ppm, 50 ppm, 35 ppm, 15 ppm, 5 ppm dan kontrol negatif tanpa larutan ekstrak $(0 \mathrm{ppm})$. Hasil penelitian ini menunjukkan bahwa setiap pelarut berpotensi sangat toksik dengan $\mathrm{LC}_{50}=12,88 \mathrm{ppm}$ pada pelarut etanol, fase n-heksana memiliki $\mathrm{LC}_{50}=1,77$ ppm dan fase etil asetat memiliki $\mathrm{LC}_{50}=19,95 \mathrm{ppm}$. $\mathrm{LC}_{50}$ tertinggi ada pada fase $\mathrm{n}$-heksana dengan $\mathrm{LC}_{50}=1,77$ ppm.
\end{abstract}

Kata Kunci $\quad$ : Kulit jeruk lemon, Artemia salina, Citrus limon, Toksisitas, BSLT

\begin{abstract}
One of the most famous plants in Indonesia is lemon (Citrus limon (L.) Osbeck). Lemon fruit is one source of vitamin $C$ and antioxidants, lemon juice ethanol extract contains secondary metabolite compounds flavonoids, glycosides, tannins, steroids, and triterpenoids. Flavonoids and triterpenoids may be toxic to some degree. For that it is necessary to do toxicity test, one of toxicity test by using method of Brine Shrimp Lethaly Test (BSLT). Toxic activity is known from the number of deaths of shrimp larvae (Artemia Salina Leach) due to the influence of extracts or natural material compounds at concentrations given. To determine the toxic potential of ethanol extract, $n$-hexane phase and ethyl acetate phase and to know the highest $L C_{50}$ value in ethanol extract, $n$-hexane phase and ethyl acetate phase. This research use experimental research type with true experimental approach. The sample used was lemon peel ethanol extract as an active substance, then in partition with n-hexane and ethyl acetate. The test solution is 1000 ppm, 600 ppm, 400 ppm, 200 ppm, 100 ppm, 50 ppm, 35 ppm, 15 ppm, 5 ppm and negative control without extract solution (0 ppm). Indicates that each solvent is potentially very toxic with $L C_{50}=12.88$ ppm in ethanol solvent, the $n$-hexane phase has $L C_{50}=$ $1.77 \mathrm{ppm}$ and the ethyl acetate phase has $L C_{50}=19.95 \mathrm{ppm}$. The highest $L C_{50}$ is in the $n$-hexane phase with $L C_{50}=1.77 \mathrm{ppm}$.
\end{abstract}

Keywords $\quad$ : Lemon peel, Artemia salina, Citrus limon, Toxicity, BSLT 


\section{PENDAHULUAN}

Di Negara Asia terutama Cina, Korea dan India untuk penduduk pedesaan, obat herbal menjadi pilihan pertama untuk pengobatan. Di Negara maju seperti Australia, Canada (59-60\%), Amerika Serikat (62\%), Singapura (76\%) dan Jepang $(50 \%)$ pun saat ini cenderung beralih ke pengobatan tradisional terutama obat herbal menunjukkan gejala peningkatan yang sangat signifikan (Kurdi, 2010). Di Indonesia sendiri pemanfaatan tanaman sebagai bahan obat sudah sejak lama dilakukan oleh masyarakat. Dengan keanekaragaman etnis yang ada, maka pemanfaatan tanaman sebagai obat juga semakin beranekaragam (Handayani, 2015).

Kekayaan alam Indonesia, menyimpan berbagai tumbuhan yang berkhasiat obat dari 40 ribu jenis tumbuhan yang tumbuh di dunia, 30 ribu diantaranya tumbuh di Indonesia. Sebanyak $26 \%$ yang telah dibudidayakan dan $74 \%$ masih tumbuh liar di hutan. Dari $26 \%$ yang telah dibudidayakan, sebanyak 940 jenis tanaman telah digunakan sebagai obat tradisional, sedangkan menurut WHO, lebih dari 20.000 spesies tumbuhan berkhasiat obat digunakan oleh penduduk di seluruh dunia (Arsyah, 2014).
Salah satu tanaman di Indonesia yang sangat terkenal yaitu jeruk lemon (Citrus limon (L.) Osbeck). Jeruk lemon merupakan salah satu bahan alami yang dapat dimanfaatkan buah dan kulitnya. Buah lemon mengandung asam-asam yang berperan pada pembentukan rasa asam buah. Buah lemon merupakan salah satu sumber vitamin $\mathrm{C}$ dan antioksidan yang berkhasiat bagi kesehatan manusia, tetapi sebenarnya buah ini juga mengandung zat gizi esensial lainnya, seperti karbohidrat, potassium, folat, kalsium, thiamin, niacin, vitamin $\mathrm{B}_{6}$, fosfor, magnesium, tembaga, riboflavin, asam pantotenant, dan senyawa fitokimia. (Nizhar, 2012). Kulit lemon terdiri dari dua lapisan yaitu lapisan luar dan lapisan dalam. Lapisan luar, mengandung minyak esensial yang terdiri dari citral (5\%) dan limonen, $\alpha$-terpineol, geranil asetat dan linali. Lapisan dalam, mengandung kumarin, glikosida dan flavonoid (Dev, 2016). Menurut Chitra (2012), ekstrak etanol kulit jeruk lemon mengandung senyawa metabolit sekunder flavonoid, glikosida, tanin, steroid, dan triterpenoid.

Senyawa flavonoid dan triterpenoid diduga dapat bersifat toksik pada kadar tertentu (Cahyadi, 2009). Untuk itu perlu dilakukannya uji toksisitas, salah satu 
pengujian toksisitas dengan menggunakan metode Brine Shrimp Lethaly Test (BSLT). Beberapa keuntungan menggunakan metode BSLT adalah metode yang telah teruji untuk mengamati toksisitas suatu senyawa di dalam ekstrak kasar tumbuhan dengan tingkat kepercayaan 95\%, metode penapisan farmakologi awal yang mudah, cepat dan murah, metode ini sering digunakan untuk pencarian senyawa antikanker dan tahap awal isolasi senyawa toksik yang terkandung dalam suatu ekstrak (Lindawati, 2006). Aktivitas toksik diketahui dari jumlah kematian larva udang (Artemia Salina Leach) karena pengaruh ekstrak atau senyawa bahan

\section{METODE}

\section{Bahan}

Ekstrak kulit jeruk lemon (Citrus limon (L.) Osbeck), Etanol 70\%, telur udang (Artemia salina Leach), Aquadest, N-Heksan dan Etil Asetat.

\section{Pembuatan ekstrak etanol}

400 mg serbuk kulit jeruk lemon di maserasi dalam 3 liter etanol selama 3 hari. Ekstrak dievaporasi sampai diperoleh ekstrak kental.

\section{Pembuatan partisi ekstrak}

4 gram ekstrak dilarutkan dengan n-heksan kemudian dilarutkan dengan 20 alam pada konsentrasi yang diberikan (Silva, 2007). Suatu ekstrak atau senyawa bahan alam yang diketahui memiliki aktivitas toksik melalui metode BSLT (nilai $\mathrm{LC}_{50}<1000 \mathrm{ppm}$ ) dapat dikembangkan lebih lanjut sebagai obat antikanker (Meyer,1982).

Berdasarkan uraian di atas dapat diketahui masalah dalam penelitian ini adalah masih banyak tanaman yang belum diketahui kadar toksisitasnya sehingga perlu diteliti lebih lanjut. Oleh karena itu, peneliti bermaksud untuk melakukan penelitian yang berjudul "Uji toksisitas ekstrak kulit jeruk lemon (Citrus limon (L.) Osbeck) Terhadap Larva Udang (Artemia salina Leach)".

ml aquadest, setelah larut masukkan ke dalam corong pisah dan tambahkan nheksan $30 \mathrm{ml}, 20 \mathrm{ml}$ dan $15 \mathrm{ml}$ dilakukan pengocokan sebanyak 3 kali. Kocok hingga rata, sekali -kali buka penutup corong pisah kemudian diamkan sampai terjadi pemisahan dari fase air dan fase nheksan. Kemudian hasil fase air di partisi lagi dengan etil asetat sebanyak $30 \mathrm{ml}, 20$ $\mathrm{ml}$ dan $15 \mathrm{ml}$ dilakukan 3 kali pengocokan. Fase n-heksan dan fase etil etil asetat dievaporasi sampai diperoleh ekstrak kental. 


\section{Penetasan larva udang}

Untuk penetasan larva udang dengan menggunakan botol air mineral yang dibagi menjadi dua bagian. Bagian atas penutup botol dimasukan ke bagian bawah lalu dilubangi untuk jalan masuknya selang yang terhubung dengan aerator, lalu dihidupkan aerator. Kemudian dituangkan air laut ke dalam botol, selanjutnya dituangkan 1 sendok teh telur udang, lalu didiamkan selama 48 jam. Dipisahkan cangkang telur dengan larva yang sehat dan bergerak aktif ke dalam wadah yang berbeda.

\section{Pembuatan konsentrasi ekstrak yang akan diuji}

Ekstrak kental kulit jeruk lemon (Citrus limon (L.) Osbeck) ditimbang sebanyak $200 \mathrm{mg}$, dilarutkan dengan air laut sebanyak $100 \mathrm{~mL}$. larutan tersebut digunakan sebagai larutan induk dengan konsentrasi 2000 ppm. Konsentrasi yang digunakan untuk pengujian yang dilakukan secara dua kali (duplo) ini yaitu 1000 ppm, 600 ppm, 400 ppm, 200 ppm, 100 ppm, 50 ppm, 35 ppm, 15 ppm dan 5 ppm.

\section{Uji toksisitas dengan metode BSLT}

Pada uji BSLT akan digunakan tabung reaksi. Langkah pertama yang dilakukan adalah membagi 9 kelompok tabung untuk masing-masing konsentrasi dan 1 kelompok untuk kontrol negatif. Percobaan ini dilakukan pengulangan 2 (duplo). 10 ekor larva udang dimasukkan kedalam tabung reaksi yang berisi masing-masing $10 \mathrm{ml}$ pada setiap konsentrasi. Kemudian tabung dibiarkan di udara terbuka selama 24 jam. Lalu lakukan perhitungan larva yang mati.

\section{HASIL}

\section{Uji Toksisitas Ekstrak Kulit Jeruk Lemon (Citrus limon (L.) Osbeck)}

\section{a. Ekstrak Etanol Kulit Jeruk Lemon (Citrus limon (L.) Osbeck)}

Tabel 1. Hasil Uji Toksisitas Ekstrak Etanol Kulit Jeruk Lemon (Citrus limon (L.) Osbeck) dengan Nilai $\mathrm{LC}_{50}$.

\begin{tabular}{cccc}
\hline Konsentrasi (ppm) & \% Kematian & Probit & Nilai LC $\mathbf{C}_{\mathbf{5 0}}(\mathbf{p p m})$ \\
\hline 0 & 0 & 0 & 0,0 \\
5 & 40 & 4,7467 & \\
15 & 45 & 4,8743 & \\
35 & 90 & 6,2816 & \\
50 & 100 & 8,719 & \\
100 & 100 & 8,719 & 12,88 \\
200 & 100 & 8,719 & \\
400 & 100 & 8,719 & \\
600 & 100 & 8,719 & \\
1000 & 100 & 8,719 & \\
\hline
\end{tabular}




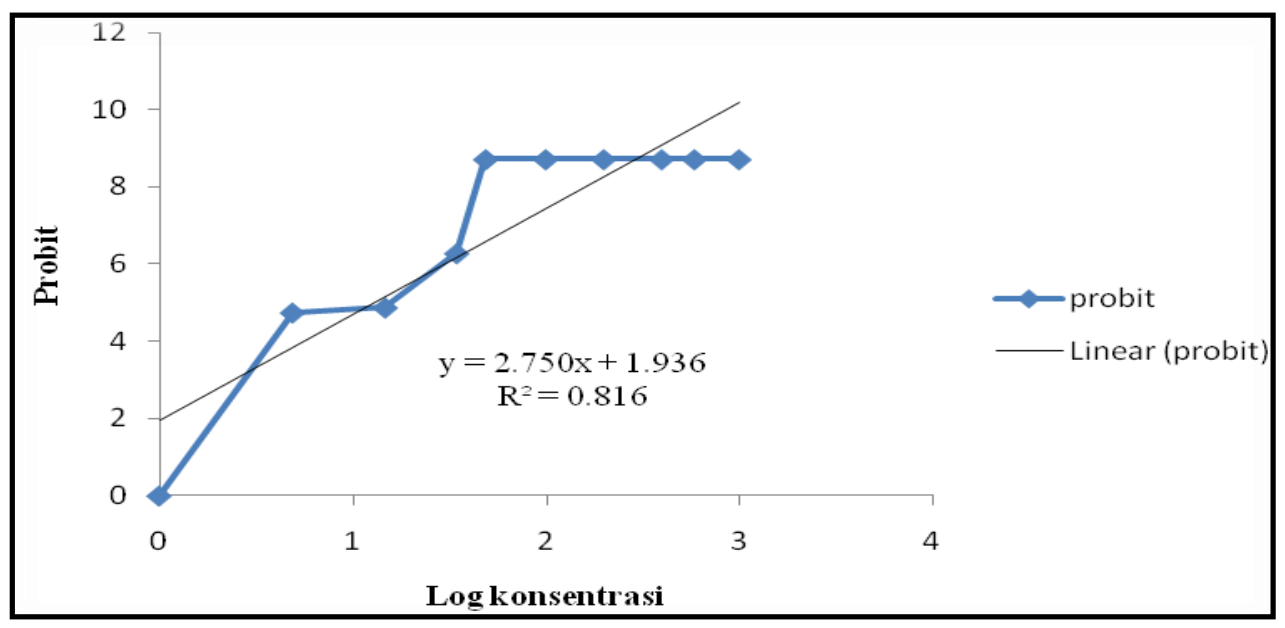

Gambar 1. Grafik Analisis Regresi Linier Ekstrak Etanol Kulit Jeruk Lemon (Citrus limon (L.) Osbeck)

Berdasarkan tabel 1. hasil uji toksisitas ekstrak etanol kulit jeruk lemon (Citrus limon (L.) Osbeck) dengan nilai $\mathrm{LC}_{50}$, terdapat berbagai macam konsentrasi sehingga menghasilkan persen kematian dan probit yang berbeda pula. Pada konsentrasi 0 ppm yang digunakan sebagai kontrol negatif, menghasilkan persen kematian sebanyak $0 \%$, probitnya yaitu 0 dan nilai $\mathrm{LC}_{50}$ yaitu 0,0 ppm karena pada konsentrasi 0 ppm tidak menggunakan ekstrak. Pada konsentrasi 5 ppm, menghasilkan persen kematian sebanyak $40 \%$ dan probitnya yaitu 4,7467. Pada konsentrasi 15 ppm, menghasilkan persen kematian sebanyak $45 \%$ dan probitnya yaitu 4,8743. Pada konsentrasi 35 ppm, menghasilkan persen kematian sebanyak $90 \%$ dan probitnya yaitu 6,2816. Pada konsentrasi 50 ppm, 100 ppm, 200 ppm, 400 ppm, 600 ppm dan 1000 ppm, menghasilkan persen kematian $100 \%$ dan probitnya 8,719. Pada konsentrasi 5 ppm, 15 ppm, 35 ppm, 50 ppm, 100 ppm, 200 ppm, 400 ppm, 600 ppm dan 1000 ppm menghasilkan nilai $\mathrm{LC}_{50}$ sebesar $12,88 \mathrm{ppm}$.

Berdasarkan gambar 1. grafik analisis regresi linier ekstrak etanol kulit jeruk lemon (Citrus limon (L.) Osbeck), diperoleh persamaan regresi linier dengan nilai persamaan yaitu $\mathrm{y}=$ $2,750 \mathrm{x}+1,936$ dan nilai $\mathrm{R}^{2}=0,816$. 
b. Fase n-Heksana Ekstrak Kulit Jeruk Lemon (Citrus limon (L.) Osbeck)

Tabel 2. Hasil Uji Toksisitas Fase n-Heksana Ekstrak Kulit Jeruk Lemon (Citrus limon (L.) Osbeck) dengan Nilai $\mathrm{LC}_{50}$

\begin{tabular}{cccc}
\hline Konsentrasi (ppm) & \% Kematian & Probit & Nilai LC $\mathbf{L C}_{\mathbf{5 0}}(\mathbf{p p m})$ \\
\hline 0 & 0 & 0 & 0,0 \\
5 & 100 & 8,719 & \\
15 & 100 & 8,719 & \\
35 & 100 & 8,719 & \\
50 & 100 & 8,719 & \\
100 & 100 & 8,719 & 1,77 \\
200 & 100 & 8,719 & \\
400 & 100 & 8,719 & \\
600 & 100 & 8,719 & \\
1000 & 100 & 8,719 & \\
\hline
\end{tabular}

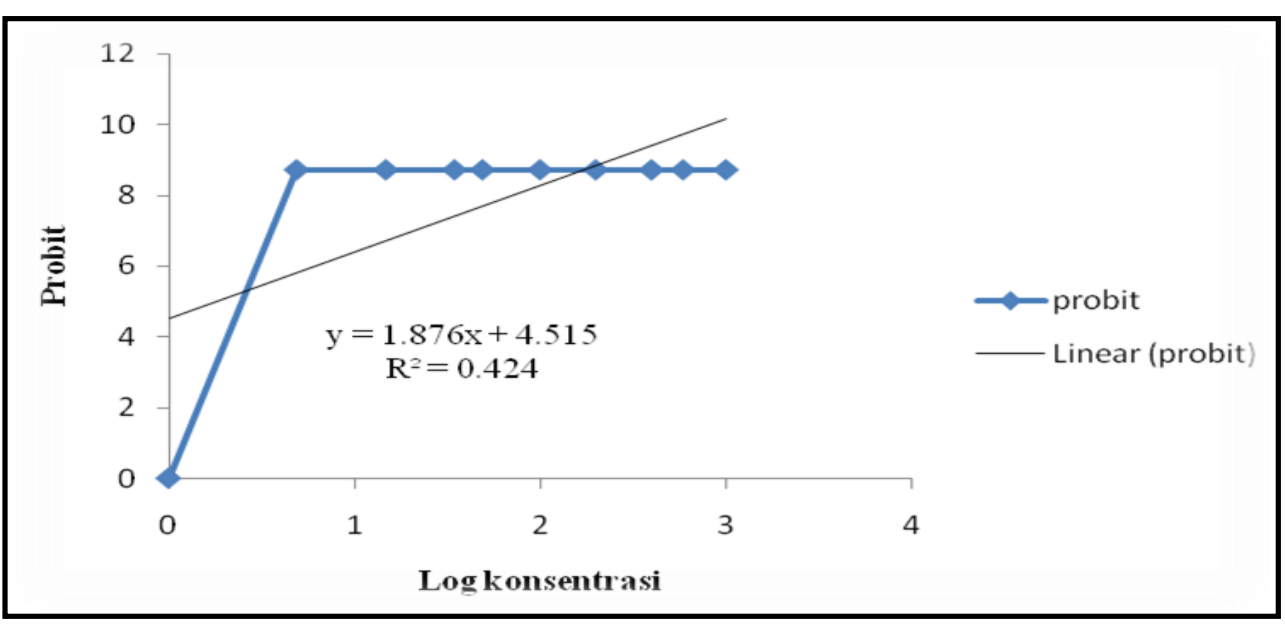

Gambar 2. Grafik Analisis Regresi Linier Fase n-Heksana Ekstrak Kulit Jeruk Lemon (Citrus limon (L.) Osbeck)

Berdasarkan tabel 2. hasil uji toksisitas fase n-heksana ekstrak kulit jeruk lemon (Citrus limon (L.) Osbeck) dengan nilai $\mathrm{LC}_{50}$, terdapat berbagai macam konsentrasi sehingga menghasilkan persen kematian dan probit yang berbeda pula. Pada konsentrasi 0 ppm yang digunakan sebagai kontrol negatif, menghasilkan persen kematian sebanyak $0 \%$, probitnya yaitu 0 dan nilai $\mathrm{LC}_{50}$ yaitu 0,0 ppm karena pada konsentrasi 0 ppm tidak menggunakan ekstrak. Pada konsentrasi 5 ppm, 15 ppm, 35 ppm, 50 ppm, 100 ppm, 200 ppm, 400 ppm, 600 ppm dan 1000 ppm, menghasilkan persen kematian 100\%, probitnya 8,719 dan nilai $\mathrm{LC}_{50}$ sebesar 1,77 ppm.

Berdasarkan gambar 2 grafik analisis regresi linier fase n-heksana 
ekstrak kulit jeruk lemon (Citrus limon yaitu $y=1,876 x+4,515$ dan nilai $R^{2}$

(L.) Osbeck, diperoleh persamaan $=0,424$.

regresi linier dengan nilai persamaan

c. Fase Etil Asetat Ekstrak Kulit Jeruk Lemon (Citrus limon (L.) Osbeck)

Tabel 3. Hasil Uji Toksisitas Fase Etil Asetat Kulit Jeruk Lemon (Citrus limon (L.) Osbeck) dengan Nilai $\mathrm{LC}_{50}$

\begin{tabular}{cccc}
\hline Konsentrasi (ppm) & \%Kematian & Probit & Nilai $\mathbf{L C}_{\mathbf{5 0}}(\mathbf{p p m})$ \\
\hline 0 & 0 & 0 & 0,0 \\
5 & 15 & 3,9636 & \\
15 & 15 & 3,9636 & \\
35 & 15 & 3,9636 & \\
50 & 100 & 8,719 & \\
100 & 100 & 8,719 & 19,95 \\
200 & 100 & 8,719 & \\
400 & 100 & 8,719 & \\
600 & 100 & 8,719 & \\
1000 & 100 & 8,719 & \\
\hline
\end{tabular}

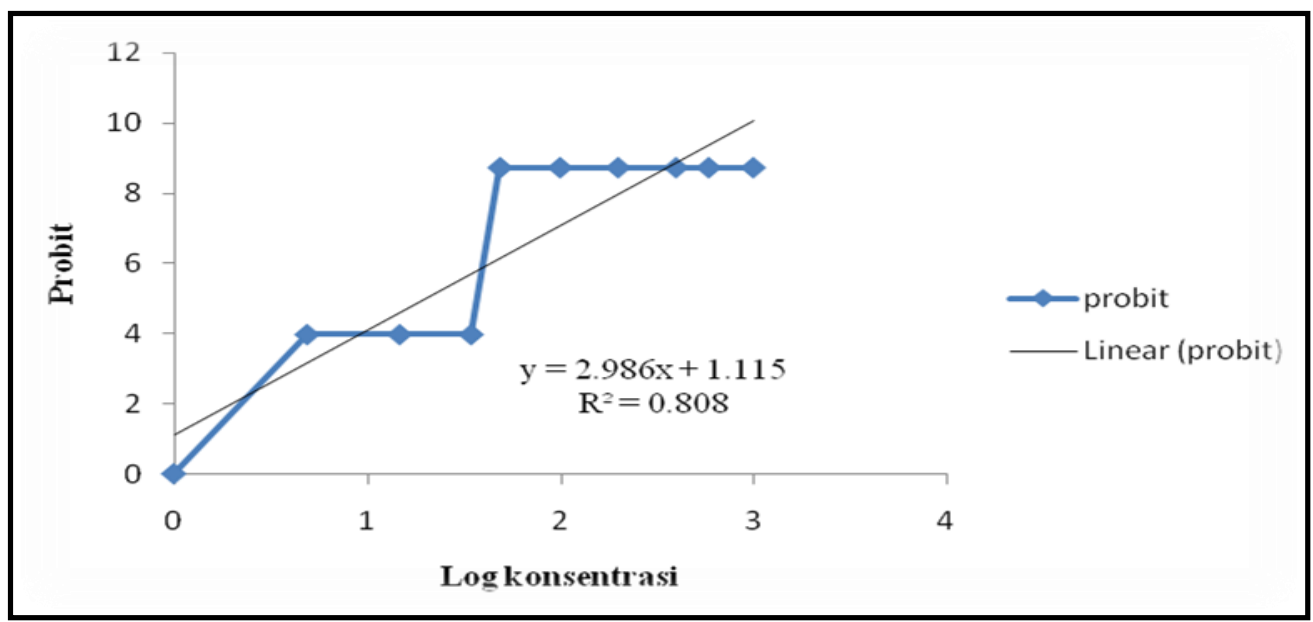

Gambar 3. Grafik Analisis Regresi Linier Fase Etil Asetat Ekstrak Kulit Jeruk Lemon (Citrus limon (L.) Osbec

Berdasarkan tabel 3. hasil uji toksisitas fase etil asetat ekstrak kulit jeruk lemon (Citrus limon (L.) Osbeck) dengan nilai $\mathrm{LC}_{50}$, terdapat berbagai macam konsentrasi sehingga menghasilkan persen kematian dan probit yang berbeda pula. Pada konsentrasi 0 ppm yang digunakan sebagai kontrol negatif, menghasilkan persen kematian sebanyak $0 \%$, probitnya yaitu 0 dan nilai $\mathrm{LC}_{50}$ yaitu 0,0 ppm karena pada konsentrasi 0 ppm tidak menggunakan ekstrak. Pada konsentrasi 5 ppm, 15 ppm dan 35 ppm menghasilkan persen kematian sebanyak $15 \%$ dan probitnya 3,9636. 
Pada konsentrasi 50 ppm, 100 ppm, 200 ppm, 400 ppm, 600 ppm dan 1000 ppm, menghasilkan persen kematian $100 \%$ dan probitnya 8,719. Pada konsentrasi 5 ppm, 15 ppm, 35 ppm, 50 ppm, 100 ppm, 200 ppm, 400 ppm, 600 ppm dan 1000 ppm menghasilkan nilai $\mathrm{LC}_{50}$ sebesar $19,95 \mathrm{ppm}$.
Berdasarkan gambar 3. grafik analisis regresi linier fase etil asetat ekstrak kulit jeruk lemon (Citrus limon (L.) Osbeck) diperoleh persamaan regresi linier dengan nilai persamaan yaitu $\mathrm{y}=2,986 \mathrm{x}+1,115$ dan nilai $\mathrm{R}^{2}$ $=0,808$.

\section{DISKUSI}

\section{Uji Toksisitas Ekstrak Kulit Jeruk Lemon (Citrus limon (L.) Osbeck)}

Uji toksisitas pada penelitian ini menggunakan metode BSLT (Brine Shrimp Lethality Test). Metode ini menggunakan hewan coba berupa larva udang (Artemia salina Leach) karena spesies ini memiliki kesamaan tipe DNA dan RNA dengan mamalia. Dimana tipe DNA-dependent RNA polymerase yang dimiliki oleh Artemia salina Leach sama dengan mamalia.

Adapun fungsi yang dimiliki oleh DNA-dependent RNA polymerase yaitu untuk pembentukan protein dan protein merupakan komponen utama semua sel. Jadi ketika DNA-dependent RNA polymerase dihambat maka tidak akan terjadi pembukaan pilinan DNA menjadi RNA, lalu tidak terjadi juga penerjemah kodon pada tiap-tiap kodon yang ada di RNA tersebut sehingga tidak dapat terbentuk protein baru. Penghentian pembentukan protein ini akan menyebabkan gangguan metabolisme dan akhirnya menyebabkan kematian sel (Reskianigsih, 2014).

Uji toksisitas dilakukan untuk mengetahui $\mathrm{LC}_{50}$ pada suatu bahan alam. Kategori $\mathrm{LC}_{50}$ adalah $\mathrm{LC}_{50} \geq 1000 \mathrm{ppm}$ termasuk dalam kategori tidak toksik, $\mathrm{LC}_{50}$ 30-1000 ppm termasuk dalam kategori toksik dan $\mathrm{LC}_{50} \leq 30 \mathrm{ppm}$ termasuk dalam kategori sangat toksik (McLauughlin, 1998).

Sampel yang digunakan yaitu ekstrak kulit jeruk lemon (Citrus limon (L.) Osbeck) yang diperoleh menggunakan metode ekstraksi. Metode ekstraksi yang digunakan adalah maserasi dengan pelarut etanol. Serbuk simplisia kulit jeruk lemon sebanyak 400 gram direndam dengan etanol selama 3 hari kemudian disaring, lalu filtrat dikentalkan dengan water bath hingga menjadi ekstrak kental kemudian ekstrak kental di partisi dengan n-heksana dan etil asetat. Adapun penggunaan pelarut berdasarkan tingkat polaritas. 
Pelarut polar menggunakan etanol, pelarut semi polar yang digunakan etil asetat dan pelarut non polar yang digunakan nheksan. Pemilihan pelarut yang berbeda ini dimaksudkan agar senyawa-senyawa yang memiliki kepolaran berbeda dapat larut ke dalam pelarut yang sesuai.

Pemilihan Etanol sebagai perlarut karena lebih efektif, kapang dan bakteri sulit tumbuh dalam etanol diatas $20 \%$, tidak beracun, netral, absorbsinya baik, etanol dapat bercampur dengan air pada segala perbandingan, panas yang diperlukan untuk pemekatan lebih sedikit.

Etanol dapat melarutkan alkaloid, kurkumin, kumarin, glikosida, flavonoid, steroid, lemak, tanin dan saponin hanya sedikit larut (Sa'adah, 2015). Pemilihan n-heksana sebagai pelarut karena mudah diuapkan, relatif aman dan murah. Pelarut n-heksan dapat digunakan untuk melarutkan senyawa metabolit sekunder seperti steroid, lemak, sterol, kumarin, dan terpenoid (Tanaya, 2015).

Adapun pemilihan etil asetat sebagai pelarut karena mudah menguap (bersifat volatil), berwujud cairan yang tidak beracun, tidak berwarna dan memiliki aroma khas (Ocktaviandini, 2015). Pelarut etil asetat dapat digunakan untuk melarutkan senyawa metabolit sekunder seperti flavonoid, triterpenoid dan tanin (Tanaya, 2015).
Pada penelitian ini menggunakan berbagai konsentrasi yaitu 1000 ppm, 600 ppm, 400 ppm, 200 ppm, 100 ppm, 50 ppm, 35 ppm, 15 ppm, 5 ppm dan 0 ppm (kontrol negatif) untuk mengetahui pada konsentrasi mana yang memiliki $\mathrm{LC}_{50}$ (Lethal Concentration 50). Penelitian ini sudah sesuai dengan teori karena untuk mendapat ekstrak yang dinyatakan toksik menggunakan konsentrasi dibawah 1000 ppm.

a. Ekstrak Etanol Kulit Jeruk Lemon (Citrus limon (L.) Osbeck)

Hasil skrining fitokimia menunjukkan bahwa ekstrak etanol kulit jeruk lemon mengandung flavonoid, triterpenoid, steroid dan tanin. Berdasarkan penelitian yang dilakukan oleh Chitra (2012), senyawa metabolit sekunder pada ekstrak etanol kulit jeruk lemon adalah flavonoid, glikosida, tanin, steroid/ triterpenoid.

Berdasarkan tabel 1. hasil uji toksisitas ekstrak etanol kulit jeruk lemon (Citrus limon (L.) Osbeck) dengan nilai $\mathrm{LC}_{50}$, terdapat berbagai macam konsentrasi sehingga menghasilkan persen kematian dan probit yang berbeda pula. Pada konsentrasi 0 ppm yang digunakan sebagai kontrol negatif, menghasilkan persen kematian sebanyak $0 \%$, probitnya yaitu 0 dan nilai $\mathrm{LC}_{50}$ yaitu 
0,0 ppm karena pada konsentrasi 0 ppm tidak menggunakan ekstrak.

Pada konsentrasi 5 ppm, menghasilkan persen kematian sebanyak $40 \%$ dan probitnya yaitu 4,7467. Pada konsentrasi 15 ppm, menghasilkan persen kematian sebanyak $45 \%$ dan probitnya yaitu 4,8743. Pada konsentrasi 35 ppm, menghasilkan persen kematian sebanyak $90 \%$ dan probitnya yaitu 6,2816. Pada konsentrasi 50 ppm, 100 ppm, 200 ppm, 400 ppm, 600 ppm dan 1000 ppm, menghasilkan persen kematian $100 \%$ dan probitnya 8,719 .

Pada konsentrasi 5 ppm, 15 ppm, 35 ppm, 50 ppm, 100 ppm, 200 ppm, 400 ppm, 600 ppm dan 1000 ppm menghasilkan nilai $\mathrm{LC}_{50}$ sebesar 12,88 ppm, termasuk kategori sangat toksik. Hal ini sesuai dengan McLauughlin (1998) yang menyatakan bahwa $\mathrm{LC}_{50} \leq$ 30 ppm termasuk dalam kategori sangat toksik. Perhitungan $\mathrm{LC}_{50}$ dapat dilihat pada lampiran 18 .

Berdasarkan gambar 1 grafik analisis regresi linier ekstrak etanol kulit jeruk lemon (Citrus limon (L.) Osbeck), diperoleh persamaan regresi linier dengan nilai persamaan yaitu $\mathrm{y}=$ $2,750 x+1,936$ dan nilai $R^{2}=0,816$.

Pada penelitian ini didapatkan bahwa ekstrak kulit jeruk lemon mempunyai potensi toksisitas. Hal tersebut berkaitan dengan senyawa yang terdapat dalam kulit jeruk lemon yang dapat menyebabkan kematian larva. Mekanisme kematian pada larva disebabkan oleh adanya flavonoid yang berperan sebagai stomach poisoning (racun perut). Proses ini menyebabkan larva mengalami gangguan pada saluran cernanya.

Selain itu, senyawa ini menghambat reseptor rasa yang berada di permukaan mulut larva sehingga larva tidak bisa mendeteksi makanan dan akhirnya mati karena kelaparan (Reskianingsih, 2014). Berdasarkan dari pernyataan tersebut maka senyawa yang terdapat pada ekstrak kulit jeruk lemon yang berperan sebagai racun perut pada larva udang sehingga menyebabkan kematian larva adalah flavonoid.

\section{b. Fase n-Heksana Ekstrak Kulit Jeruk Lemon (Citrus limon (L.) Osbeck)}

Berdasarkan tabel 2 hasil uji toksisitas fase n-heksana ekstrak kulit jeruk lemon (Citrus limon (L.) Osbeck) dengan nilai $\mathrm{LC}_{50}$, terdapat berbagai macam konsentrasi sehingga menghasilkan persen kematian dan probit yang berbeda pula.

Pada konsentrasi 0 ppm yang digunakan sebagai kontrol negatif, menghasilkan persen kematian 
sebanyak $0 \%$, probitnya yaitu 0 dan nilai $\mathrm{LC}_{50}$ yaitu 0,0 ppm karena pada konsentrasi 0 ppm tidak menggunakan ekstrak. Pada konsentrasi 5 ppm, 15 ppm, 35 ppm, 50 ppm, 100 ppm, 200 ppm, 400 ppm, 600 ppm dan 1000 ppm, menghasilkan persen kematian $100 \%$, probitnya 8,719 dan nilai $\mathrm{LC}_{50}$ sebesar 1,77 ppm termasuk ke dalam kategori sangat toksik. Hal ini sesuai dengan McLauughlin (1998) bahwa $\mathrm{LC}_{50} \leq 30 \mathrm{ppm}$ termasuk dalam kategori sangat toksik. Perhitungan $\mathrm{LC}_{50}$ dapat dilihat pada lampiran 18.

Pada fase n-heksana didapatkan bahwa kematian larva mencapai $100 \%$ hal ini diduga bahwa senyawa non polar dapat larut sempurna. Senyawa non polar pada kulit jeruk lemon yang penyebabkan kematian larva adalah triterpenoid. Tritepenoid berperan sebagai stomach poisoning atau racun perut (Nguyen, 1999).

Senyawa toksik yang ada pada ekstrak dapat masuk melalui bagian mulut larva dan diabsorbsi masuk ke dalam saluran pencernaan terjadi proses absorbsi melalui membran sel. Setelah proses absorbsi dilanjutkan dengan distribusi senyawa toksik ke dalam tubuh larva. Perubahan gradient konsentrasi yang drastic antara di dalam dan diluar sel yang menyebabkan senyawa toksik mampu meyebar dengan baik ke dalam tubuh larva. Efek kerusakan metabolisme yang ditimbulkan terjadi secara cepat dapat dideteksi dalam waktu 24 jam hingga menyebabkan 50\% kematian larva (Ningsyah, et al, 2015).

\section{c. Fase Etil Asetat Ekstrak Kulit Jeruk Lemon (Citrus limon (L.) Osbeck)}

Berdasarkan tabel 4.3 hasil uji toksisitas fase etil asetat ekstrak kulit jeruk lemon (Citrus limon (L.) Osbeck) dengan nilai $\mathrm{LC}_{50}$, terdapat berbagai macam konsentrasi sehingga menghasilkan persen kematian dan probit yang berbeda pula.

Pada konsentrasi 0 ppm yang digunakan sebagai kontrol negatif, menghasilkan persen kematian sebanyak $0 \%$, probitnya yaitu 0 dan nilai $\mathrm{LC}_{50}$ yaitu 0,0 ppm karena pada konsentrasi 0 ppm tidak menggunakan ekstrak. Pada konsentrasi 5 ppm, 15 ppm dan 35 ppm menghasilkan persen kematian sebanyak $15 \%$ dan probitnya 3,9636. Pada konsentrasi 50 ppm, 100 ppm, 200 ppm, 400 ppm, 600 ppm dan 1000 ppm, menghasilkan persen kematian $100 \%$ dan probitnya 8,719 .

Pada konsentrasi 5 ppm, 15 ppm, 35 ppm, 50 ppm, 100 ppm, 200 ppm, 400 ppm, 600 ppm dan 1000 ppm menghasilkan nilai $\mathrm{LC}_{50}$ sebesar 19,95 ppm termasuk kategori sangat toksik. 
Hal ini sesuai dengan McLauughlin (1998) bahwa $\mathrm{LC}_{50} \leq 30$ ppm termasuk dalam kategori sangat toksik.

Pada fase etil asetat terdapat senyawa semi polar yang bersifat toksik di duga dapat menyebabkan kematian adalah tanin. Tanin pada umumnya menghambat aktivitas enzim dengan jalan membentuk ikatan kompleks dengan protein pada enzim substrat yang dapat menyebabkan gangguan pencernaan dan merusak dinding sel, sehingga mekanisme kerja tanin sebagai racun perut (Sumilih, 2010).

Setiap pelarut berpotensi sangat toksik tetapi $\mathrm{LC}_{50}$ tertinggi ada pada pelarut $\mathrm{n}$-heksan dengan $\mathrm{LC}_{50}=1,77$ ppm dapat dilihat pada tabel 4.3 hasil uji toksisitas fase n-heksana ekstrak kulit jeruk lemon (Citrus limon (L.) Osbeck) dengan nilai $\mathrm{LC}_{50}$. Alasan ekstrak kulit jeruk lemon memiliki tingkat toksisitas tertinggi pada pelarut non polar karena senyawa ekstrak kulit jeruk lemon yang menyebabkan toksik dapat larut dengan baik pada pelarut non polar.

\section{SIMPULAN}

Dari penelitian yang telah dilakukan terhadap ekstrak kulit jeruk lemon ini, dapat diambil kesimpulan bahwa pada
Berdasarkan hasil uji toksisitas ekstrak kulit jeruk lemon (Citrus limon (L.) Osbeck) menunjukkan hasil yang sangat toksik sehingga perlu adanya perhatian mengenai penggunaan kulit jeruk lemon sebagai obat tradisional. Selain itu, perlu dilakukan uji keamanan dosis penggunaan kulit jeruk lemon sehingga dapat dijadikan obat tradisional.

Menurut PERMENKES No.760/MENKES/PER/IX/ 1992 tentang Fitofarmaka, menyatakan bahwa obat tradisional yang didaftarkan sebagai jamu harus melengkapi uji toksisitas dan uji farmakologi eksperimental untuk memastikan keamanan bahan alam tersebut. Hal ini sesuai dengan meyer (1982) yang menyatakan bahwa suatu ekstrak atau senyawa bahan alam yang diketahui memiliki toksik melalui metode BSLT (nilai LC $_{50}<1000$ ppm) dapat dikembangkan lebih lanjut sebagai obat antikanker.

Berdasarkan pernyataan tersebut maka, ekstrak kulit jeruk lemon ini dapat di kembangkan sebagai obat antikanker di masa yang akan datang.

ekstrak kulit jeruk lemon (Citrus limon (L.) Osbeck) memiliki toksisitas terhadap larva udang (Artemia salina Leach), 
sedangkan pada ekstrak etanol, fase nheksan dan fase etil asetat memiliki sangat toksik dengan nilai $\mathrm{LC}_{50} \quad 12,88$ ppm, $\mathrm{LC}_{50} 1,77$ ppm dan $\mathrm{LC}_{50} 19,95$ ppm,

\section{DAFTAR PUSTAKA}

Arsyah CD. 2014. Kajian Etnobotani Tanaman Obat Herbal Dan Pemanfaatannya Dalam Usaha Menunjang Kesehatan Keluarga Di Dusun Turgo, Purwobinangun, Pake, Sleman. [Skripsi]. Fakultas Sains dan Teknologi. Universitas Islam Negeri Sunan Kalijaga. Yogyakarta.

Cahyadi R. 2009. Uji Toksisitas Akut Ekstrak Etanol Buah Pare (Momordica Charantia L) Terhadap Larva Artemia Salina Leach Dengan Metode Brine Shrimp Lethality Test (BST). [Skripsi]. Fakultas Kedokteran. Universitas Diponegoro.

Semarang

Chitra, D BR Ginting. 2012. Karakteristik Simplisia Dan Skrining Fitokimia Serta Uji Aktivitas Antioksidan Ekstrak Etanol Dari Beberapa Jenis Kulit Jeruk. [Skripsi]. Fakultas Farmasi. Universitas Sumatera Utara. Medan.

Dev C, Rishi Shrivastava RN. 2016.

Basketful Benefit Of Citrus Limon. J. Pharm Journal. 7 (6). Hal 1-6

Handayani A. 2015. Pemanfaatan Tumbuhan Berkhasiat Obat Oleh Masyarakat Sekitar Cagar Alam Gunug Simpang, Jawa Barat. Pros Sem Nas Masy Biodiv Indon Journal. Vol.1 (6). Hal.1425-1432 Lisdawati V, Wiryowidagdo $\mathrm{S}$ dan Kardono LB. 2006. Brine Shrimp Lethality Test (BSLT) Dari Berbagai Fraksi Ekstrak Daging Buah Dan Kulit Biji Mahkota dan pada fase n-heksan memiliki toksisitas paling tinggi dengan nilai $\mathrm{LC}_{50}$ sebesar 1,77 ppm yang termasuk kategori sangat toksik.

Dewa (Phaleri macrocarpa). Bul. Penelitian Kesehatan. Vol.34 (3). Hal.111-118.

McLauughlin JL, Rogers LL. 1998. The Use Of Biological Assays To Evaluate Botanicals. USA. Drug Information Journal. Vol.32. Hal 512-524.

Meyer, B.N., Ferrigni,N.R., Putnam,J.E., Jacobsen,L.B, Nichols,D.E., dan McLaughlin,J.L.1982. Brine Shrimp:A Convenient General Bioassay for Active Plant Constituents. Planta Medica Journal Vol 45 (5). Hal. 31-34

Ningdyah A R., Alimuddin A H., jayuska A. Uji Toksisitas Dengan Metode BSLT (Brine Shrimp Lethality Test) Terhadap Hasil Fraksinasi Ekstrak Kulit Buah Tampoi (Baccaurea macrocarpa). JKK Journal. Vol. 4 (1). Hal/75-83.

Nizhar M Ullyl. 2012. Level Optimum Sari Buah Lemon (Citrus limon) sebagai bahan penggumpal pada pembentukan curd keju cottage. [Skripsi]. Fakultas Peternakan. Universitas Hasanuddin. Makasar.

Ocktaviandini M. 2015. Kajian Perbedaan Konsentrasi Pelarut Etil Asetat Terhadap Karakteristik Ekstrak Zat Warna Dari Sabut Kelapa (Cocos nucifera L). [Skripsi]. Fakultas Teknik. Universitas Pasundan. Bandung

Permenkes RI. 1992. Fitofarmaka. Menteri Kesehatan Republik Indonesia. Jakarta

Reskianingsih A. 2014. Uji Toksisitas Akut Ekstrak Metanol Buah 
Phaleria macrocarpa (scheef) Boerl Terhadap Larva Artemia salina Leach Dengan Metode Brine Shrimp Lethality Test (BSLT). [Skripsi]. Fakultas Kedokteran dan Ilmu Kesehatan. Jakarta.

Sa'adah H, Nurhasnawati H. 2015. Perbandingan Pelarut Etanol dan Air Pada Pembuatan Ekstrak Umbi Bawang Tiwai (Eleutherine Americana Merr) Menggunakan Metode Maserasi. Jurnal Ilmiah Manuntung. Vol 1 (2). Hal.149153.

Silva,T.M., Nascimento,R.J., Batista, M.B.,Agra,M.F.,dan Camara,C.A. 2007. Brine Shrimp Bioassay Of Some Species Of Solanum From Northeastern Brazil. Revista Brasileirade Farmacognosia. 17(1). Hal.35-38

Sumilih S., Ambarwati, dan Dwi A. 2010. Efektivitas Ekstrak Lempuyang Wangi (Zingiber aromaticum Val.) dalam Membunuh Larva Aedes aegypti. Jurnal Kesehatan. Vol 3(10). Hal. 78-88.

Tanaya V, Retnowati R, Suratno. 2015. Fraksi Semi Polar Dari Daun Mangga Kasturi (Mangifera casturi Kosterm). Kimia Student Journal. Vol 1 (1). Hal. 778-784 
